\title{
PELATIHAN PEMANFAATAN SCRATCH SEBAGAI MEDIA PEMBELAJARAN
}

\author{
Sutikno, Susilo dan Wahyu Hardiyanto \\ Jurusan Fisika FMIPA,Universitas Negeri Semarang \\ Email: smadnasri@yahoo.com
}

\begin{abstract}
The development of computer technology more rapidly, this encourages teachers to prefer media-related computer. Lessons learned (mapel) using online media Scratch has not been done, because Scratch program includes new programs that have not been used in education. Scratch-Based Interactive Media Maple material is a medium created using the Scratch program with subject matter high school subject matter. Mapel is one of the subjects in high school subjects that still need abstract thinking. In recent years developing software (Scratch) software that can produce animation model to become one of the alternative learning media for students. The development of this media follows the $4 \mathrm{D}$ model consisting of 4 development stages: defining, designing, developing, and disseminating. Trial of the program was conducted in high school teachers conducted at SMAN 1 Mranggen and SMA Negeri 1Karang Tengah - Kab. Demak. Methods of data collection using questionnaire and documentation data. Based on data analysis then in this service hope can be implemented that Scratch-based Online Learning Media can be used as an alternative media learning.
\end{abstract}

Keywords: Learning Media, Online Learning Media, Scratch

\begin{abstract}
Abstrak. Perkembangan teknologi komputer semakin pesat, hal ini mendorong para guru untuk lebih memilih media yang berhubungan dengan komputer. Pembelajaran mata pelajaran (mapel) menggunakan media online Scratch belum banyak dilakukan, karena program Scratch termasuk program baru yang belum banyak dimanfaatkan dalam dunia pendidikan. Media interaktif berbasis Scratch Materi maple merupakan media yang dibuat menggunakan program Scratch dengan pokok bahasan materi maple SMA. Mapel merupaka salah satu materi dalam pelajaran maple di SMA yang masih membutuhkan pemikiran yang abstrak. Menghasilkan model animasi untuk menjadi salah satu alternatif media pembelajaran bagi siswa. Pengembangan media ini mengikuti model 4D yang terdiri dari 4 tahap pengembangan yaitu: pendefinisia, perancangan, pengembangan, dan penyebaran. uji coba program dilakukakan pada guru SMA yang dilaksanakan di SMAN 1 Mraggen dan SMAN 1 Karangtengan Kab.Demak. Metode pengumpulan data menggunakan data penyebaran angket dan dokumentasi. Berdasarkan analisis data maka dalam pengabdian berharap dapat dilaksanak bahwa media pembelajaran online berbasis Scratch dapat dijadikan sebagai alternatif media pembelajaran.
\end{abstract}

Kata kunci: Media Pembelajaran, Media Pembelajaran Online, Scratch 


\section{PENDAHULUAN}

Pendidikan pada hakekatnya adalah usaha sadar dan terencana untuk mewujutkan suasana belajar dan proses pembelajaran agar peserta didik secara aktif mengembangkan potensi dirinya untuk memiliki kekuatan spiritual keagamaan, pengemdali diri, kepribadian, kecerdasan, akhlak mulia serta ketrampilan yang diperlukan dirinya, masyarakat, bangsa dan negara (Munib, 1912:143). Kurikulum mengharuskan siswa mendapatkan langsung agar dapat mencapai kompetensi untuk menumbuhkan kemampuan berfikir, bekerja dan bersikap ilmiah.

Bekerja dan bersikap ilmiah salah satunya dapat dilakukan dengan ketrampilan proses sains. Ketrampilan ini menitik beratkan pada pengalaman langsung yang harus dialami oleh siswa. Ketrampilan-ketrampilan yang dapat dilakukan oleh siswa dalam ketrampilan proses sains sangat banyak, yaitu kemampuan mengobservasi, berhipotesis, mengklasifikasikan, berkomunikasi, memprediksi, interpretasi, merencanakan percobaan, menerapkan konsep, dan mengajukan pertanyaan (Rustaman, 2005:80-81).

Ada beberapa keterampilan dasar dalam mempelajari sains, salah satunya adalah kemampuan hipotesis. Dalam kegiatan hipotesis ini, sering dinamakan jawaban sementara atau dugaan terhadap rumusan masalah yang berupa pertanyaan. Pentingnya kemampuan siswa membuat hipotesis pada siswa SMA dalam pembelajaran SMA adalah dapat melatih kemampuan berfikir siswa. Berdasarkan hasil diskusi dan observasi dengan guruguru di SMA yang mengajar di kelas SMA/MA Semarang diketahui bahwa pembelajaran di SMA ummumnya menggunakan metode ceramah dan diskusi serta praktikum untuk materi tertentu. Dari kedua metode tersebut, hanya beberapa siswa yang aktif dalam proses pembelajaran dan siswa lebih banyak menerima infomasi dari guru, sehingga tidak tercipta proses pembelajaran interaktif, baik siswa dan guru maupun antar siswa.

Suatu variasi pembelajaran terprogram dengan menggunakan komputer untuk menyajikan bahan-bahan pelajaran disebut pembelajaran berbantuan komputer (Computer Assisted Instruction $=C A I)$. Program Scatch adalah suatu program yang merupakan suatu simulasi yang digunakan untuk merancang hingga menganalisis, ditampilkan dalam bentuk animasi untuk mempertunjukkan fungsi atau prinsip dasar dari suatu pembelajaran. Widhiyanto (2010:52) mengungkapkan bahwa salah satu model yang dapat digunakan dalam pelajaran teori listrik dan elektronika yaitu penggunaan program Scratchsebagai media pembelajaran dengan pendekatan PAKEM. Pembelajaran ini membuat siswa dan guru aktif, dengan demikian berkembanglah kreativitas, baik siswa maupun guru, sehingga proses ini berjalan efektif, dan akhirnya menyenangkan bagi semua. Oleh karena itu dalam pembelajaran seperti ini, siswa dituntut lebih aktif dalam mempelajari pokok bahasan hukum Ohm dan hukum Kirchoff atau tentang materi kelistrikan. Selain itu pada proses pembelajaran ini, diperlukan kemampuan untuk bekerja ilmiah atau memiliki ketrampilan ilmiah, sehingga dapat mengembangkan sikap ilmiah.

Oleh karena itu pelatihan ini berinisiatif untuk melakukan penerapan media pembelajaran berbasis Scratch pada materi SMA terhadap kemampuan mengembangkan sikap ilmiah.

Guru-guru Fisika SMA/MA, terutama di Kabupaten Demak, masih membutuhkan pendampingan dalam mengaplikasikan media pembelajaran menggunakan CAI khususnya program 
aplikasi Scratch pada materi SMA di SMA/MA. Peningkatan profesionalisme guru dalam menggunakan media pembelajaran CAI disadari oleh pemintaan ketua MGMP SMA dan para pengawas di kabupaten Demak sehingga perlu bimbingan teknis bagi mereka. Permintaan dari pengawas dinas kab Semarang dan ketua MGMP Semarang tersebut disampaikan kepada kami untuk diberikan pelatihan bagi guru-guru MGMP SMA di Demak.

Rumusan masalah kegiatan ini adalah: (1) Bagaimana pola pelatihan yang dapat meningkatkan profesional guru SMA dalam melaksanakan pembelajaran menggunakan CAI khususnya program aplikasi Scratch. (2) Seberapa besar peningkatan kemampuan dan minat guru dalam melaksanakan pembelajaran menggunakan CAI Scratch.

Tujuan umum dari pengabdian kepada masyarakat ini adalah untuk meningkatkan Profesionalisme guru-guru dalam mengimplementasikan media CAI khususnya program Scratch sesuai kurikulum di tingkat SMA/MA. Tujuan khususnya meliputi: (1) Meningkatkan kemampuan guru dalam merancang keterampilan proses sain menggunakan media CAI khususnya Scratch, dan mempublikasikan hasil karya ilmiah para siswa sebagai implikasi dari peningkatan kulaitas publikasi ilmiah gurunya, dan (3) Membentuk jaringan ilmiah ke alumni, sehingga terjalin kerjasama yang baik, serta ikut meningkatkan jenjang karier guru.

\section{METODE}

Metode yang ditawarkan dalam menyelesaikan masalah pembelajaran dengan CAI Scratch dapat dilakukan dengan beberapa. Sebelum pelatihan, melakukan pendekatan dengan pihak terkait, sehingga tahu karakteristik guru di kabupaten Demak, untuk memperlancar palatihan. Kemudian, meminta guru untuk melakukan kegiatan pada waktu yang tidak mengganggu jam pelajaran, dilakukan lewat Kepala Sekolah Di Kabupaten Demak melakukan pelatihan dan pendampingan tentang pembelajaran barbantuan CAI Scratch, dan pelatihan diawali dengan memberikan teori tentang media CAI menggunakan program aplikasi Scratch, review tentang pembelajaran di sekolah, serta aplikasinya. Sebagai tindak lanjut, direncanakan program diseminasi oleh peserta kepada guru dilingkungan sekolahnya masingmasing.

Untuk mencapai sasaran, maka target PPM ini adalah Guru yang menjadi sasaran pengabdian ini adalah guru-guru mapel SMAN Mranggen dan Karang Tengah di wilayah Kabupaten Demak. Untuk itu semua tim pengabdi telah melakukan kerjasama dengan kelompok guru-guru se Kabupaten Demak. Salah satu implikasi pendidikan dengan kurikulum adalah menjadikan peserta didik mampu mendemonstrasikan pengetahuan dan ketrampilan sesuai dengan standar yang ditetapkan dengan mengintegrasikan life skill. Mata pelajaran di SMA/MA dikembangkan dengan mengacu pada pengembangan mapel yang ditujukan untuk mendidik siswa agar mampu mengembangkan observasi dan eksperimentasoi serta berpikir taat azas. Hal ini didasari oleh tujuan pembelajaran yaitu mengamati, memahami, dan memanfaatkan gejalagejala alam yang melibatkan materi pelajaran. Kemampuan observasi dan eksperimentasi ini ditekankan pada melatih kemampuan berpikir eksperimental yang mencakup tata laksana percobaan dengan mengenal peralatan yang digunakan dalam pengukuran baik di dalam laboratorium maupun di sekitar kehidupan siswa. Dengan memahami rancang bangun rangkaian praktis ini 
diharapkan pembelajaran mapel di SMA Mranggen dan Karang Tengah berhasil sesuai tuntutan kurikulum yang berlaku di Negara kita.

Sekalipun implementasi kegiatan pengabdian kepada masyarakat ini terfokus pada guru-guru maple SMA, kegiatan ini terkait pula dengan berbagai institusi, yaitu: Kelompok Kepala Kerja Kepala Sekolah, Tim Pengabdi, Kelompok Kerja Pengawas, Dinas Pendidikan Kecamatan/Kabupaten, Komite Sekolah

Kegiatan pengabdian kepada masyarakat yang diselenggaran di aula SMAN 1 Mranggen Kabupaten Demak ini merupakan kegiatan pelatihan. Dengan demikian bentuk kegiatan dapat dikelompokkan menjadi tiga metode, yaitu:

a. Metode observasi.

Pada sesi pertama, tim pengabdian melakukan kegiatan untuk mengidentifikasi masalah.

b. Metode pelatihan.

Dilakukan untuk menanamkan pemahaman tentang program aplikasi Scratch dan implementasinya dalam materi mapel pada kelas di SMA.

c. Metode penugasan.

Kegiatan ini dilakukan untuk melakukan latihan program Scratch dalam melaksanakan pembelajaran bagi siswa.

\section{HASIL DAN PEMBAHASAN}

Salah satu materi melajaran yang ada pada mata pelajaran SMA/MA adalah materi tentang beberapa pelajaran. Dalam aplikasinya, mencakup tentang hal-hal yang sulit untuk ditunjukkan atau dijelaskan pada siswa karena sifat mapel itu sendiri yang dapat dapat disampaikan dengan teori, eksperimen menggunaan peralatan di laboratorium (jika ada), maupun bisa dilakukan dengan memanfaatkan lab maya. Dalam kegiatan ini, selain diberikan materi media dengan memanfaatkan software Scratch sebagai lab maya. Peserta juga diberikan materimateri mapel yang berkaitan dengan materi yang akan diimplementasikan dalam pembelajaran di kelas sebagai media pembelajaran menggunakan software scratch beserta kelengkapannya, seperti LCD proyektor, labtop, dan kelengkapan penunjang.

Sebelum melakukan kegiatan, tim pengabdi melakukan kontak dengan Kepala sekolah Kabupaten Demak, membuat kesepakatan bahwa pengabdian masyarakat bisa dilaksanakan pada Sabtu tanggal 15 September 2017 dan 23 September 2017, yaitu setelah jam 13.00, sehingga tidak mengganggu pelajaran. Setelah itu bersama tim membuat modul pelatihan Scratch (terlampir). Juga dilanjutkan dengan membuat file presentasi dengan format power point (*.ppt) (terlampir).

Melakukan koordinasi dengan tim pengabdi, teknisi, dan mahasiswa group riset Fisika Medik, untuk memberikan pelatihan terbaik pada peserta pelatihan guru-guru SMA se Kabupaten Demak, tgl 15 September 2017 dan 23 September 2017. Melakukan pelatihan sesuai dengan jadwal yang telah disepakati bersama, yaitu tgl 15 September 2017 dan 23 September 2017. Pelatihan dilakukan dengan metode: penyampaian teori, diskusi, praktek menggunakan software Scratch. Pembukaan dilakukan di Aula SMA Negeri 1 Mranggen Demak oleh Bpk. Prof. Dr. Sutikno, M.T, dimana pemberian teori dilakukan di Aula SMA Negeri 1 Mranggen, sedang praktek menggunakan Scratch langsung dilakukan di ruang yang sama (Gambar 1). 


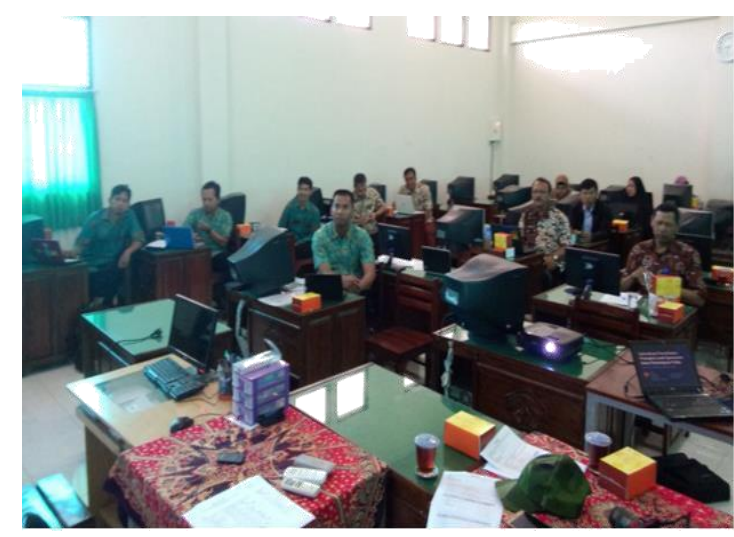

Gambar 1. Aula SMA Negeri 1 Mranggen Demak.

Pada awal kegiatan, peserta dipancing pertanyaan tentang seberapa pentingkah pembelajaran kelistrikan dalam kehidupan shari-hari. Beberapa dari peserta guru-guru SMA dengan santai menjawab karena sudah merupakan pekerjaan sehari-hari, hanya jarang menggunakan media pembelajaran yang mudah diperoleh disekitar kita. Jawaban yang lain muncul bahwa kelistrikan yang merupakan dari bagian pelajaran yang sangat bermanfaat dalam lingkungan di sekitar rumah kita. Pemberian teori tentang pembelajaran dan aplikasi dalam kehidupan sehari-hari diberikan oleh Prof. Dr.ren.nat. Wahyu hardiyanto, M.S dan Prof. Dr. Susilo, M.S.

Materi pelatihan lanjut dalam kegiatan ini disampaikan dengan metode ceramah, diskusi dan eksperimen. Penyampaian materi praktek kelistrikan dilakukan oleh Prof. Bpk. Prof. Dr. Susilo, karena kedua penyaji adalah dosen Fisika FMIPA. Materi disampaikan menggunakan alat bantu media pembelajaran berupa program aplikasi, antara lain Power Point dan Scratch. Ini dilakukan agar pembelajaran menjadi menarik, karena peserta adalah guru-guru SMA yang setiap hari sudah menyampaikan materi tersebut, sehingga secara teori mereka sudah menguasai. Dari diskusi tersebut terungkap bahwa pada umumnya peserta jarang bereksperimen dengan alat-alat bantu mengajar karena pada umumnya tidak mempunyai tenaga laboran atau teknisi, disamping beberapa sekolahan belum didukung dengan alat lab yang memadai.

Untuk melengkapi kegiatan pelatihan, dilakukan juga dengan diskusi/tanya jawab. Beberapa pertanyaan dilontarkan oleh beberapa guru, antara lain:

1) Pertanyaan peserta 1 (Bu Sri Indi Hartati, M.Pd, Guru Fisika SMAN 1 Mranggen), yaitu tentang bagaimana menyampaikaan materi hukum Kirchoof dengan mudah.

2) Pertanyaan peserta 2 (Pak Dra. Tri Mardiyanto, Guru Fisika SMAN 1 Mranggen) yaitu tentang menggunakan lab maya dan kelas maya dalam topik biologi.

3) Pertanyaan peserta 3 (Pak Solikhun, S.Pd, Guru Fisika SMAN Demak) yaitu tentang bagaimana menyampaikan mapel Matematika agar menarik meskipun keterbatan alat bantu dalam lab sangat terbatas.

\section{SIMPULAN DAN SARAN}

Secara khusus, tujuan pengabdian kepada masyarakat ini adalah untuk meningkatkan jumlah guru mapel SMA yang memahami dan mampu mengimplementasikan model pembelajaran inovatif sesuai kurikulum di tingkat SMA/MA. Setelah akhir pendampingan, guru memahami model pembelajaran inovatif untuk diterapkan dalam pembelajaran di SMA. Setelah akhir pendampingan, guru mampu membuat desain pembelajaran mapel masing-masing dengan menerapkan model pembelajaran sesuai Kurikulum, sebagaimana ditunjukkan dengan perangkat pembelajaran terkait dengan Materi mapel menggunakan media 
pembelajaran software Scrath sebagai media pembelajaran. Setelah akhir pelatihan, sekurang-kurangnya $80 \%$ guru mapel di SMAN 1Mranggen dan SMAN 1 Karang Tengah Demak mampu mengimplementasikan model pembelajaran mapel dalam pelaksanaan Kurikulum. Pengaturan waktu hendaknya bisa diatur luwes, sehingga tim pengabdi bisa menyesuaikan diri dengan kegiatan pembelajaran yang juga sudah tersusun rapi.

\section{DAFTAR PUSTAKA}

Munib, Achmad dkk. 2012. Pengantar Ilmu Pendidikan. Semarang: Universitas Negeri Semarang Press

Rustaman, N. 2003. Kemampuan Proses Imiah Dalam Pembelajaran Sains. Bandung: Universitas pendidikan Indonesia.

Rustaman, N. 2005. Strategi Belajar Mengajar Biologi. Malang: UM Press.

Widhiyanto, A. 2010. Penggunaan Program Livewire sebagai Media Pembelajaran Teori Listrik dan Elektronika Program Keahlian Tehnik Pendingin SMK Negeri 2 Kendal. Skripsi. Semarang: UNNES. 